\title{
Factors Behind the Growth of Informal Settlements in Kabul
}

\author{
Mirwais Fazli \\ Institute of Urban and Spatial Planning, Faculty of Architecture, Slovak University of \\ Technology in Bratislava \\ mirwaisfazli@yahoo.com
}

\begin{abstract}
A rapid growth of urbanization has been acknowledged by many researchers and has turned into a challenge for most countries, especially developing countries like Afghanistan. Although the theme of urbanization is new in Afghanistan, this sector has lately attracted the attention of national and international entities in Afghanistan. This is considered to be one of the biggest obstacles that hinder achieving a sustainable future development, and also prevents the implementation of the city's future master plan. At the same time, it is an obvious fact that social conflicts disturb the social life and physical form of cities, and its examples are seen throughout the world. Thus, many social, physical and economic problems are found, of which the creation of informal settlements is the prime example. Informality of urban fabric is a common subject in all developing countries. It is argued broadly throughout academic and research articles that informal settlements are created by the poor or established due to inappropriate planning systems and policies. With a fast pace, informal urban areas have now become home for a large number of people in developing countries throughout the world. In the case of Kabul, the capital city of Afghanistan, informal settlements represent up to $80 \%$ of the total city population. The study focuses on finding the factors behind the growth of informal settlements in Kabul. The purpose is to provide the notion and understanding of the way these settlements are created and their existing conditions. The paper does not suggest a model of change for the informal settlements.
\end{abstract}

KEYWORDS: informal settlements; insecurity; urban poverty; slums 


\section{Introduction}

It is widely acknowledged that a significant proportion of the urban population of Afghanistan is currently residing in property which has not been formally registered or which falls outside the formally planned parts of urban areas. The challenge of informal settlements in Afghanistan involves a wide range of complex issues. The relevant government authorities do not formally recognize informal settlements as part of the urban fabric. As a result of the discrepancy between the formal stance of the government and the reality on the ground, informal settlements have not received adequate development attention, whether in the form of orderly upgrading or the preparation of meaningful interventions aimed at improving the living conditions. A lack of sufficient basic services negatively affects the social and economic development of informal settlement inhabitants. Poor sanitation stemming from the lack of sufficient basic services results in compromised health conditions of the inhabitants.

In 1999 the population within Kabul city was 1.79 million but now, after 15 years, it has reached about 5 million. (1) This kind of unplanned population growth can even get developed countries into big trouble. The Afghan government and their global partners have been too busy with other issues, especially security, which is why the alignment of the infrastructure of Kabul city with the population has been totally neglected.

The latest master plan of Kabul city was created in 1978 but afterwards, due to many occurrences, the plan was never implemented. Ultimately, on the basis of the previous master plan and according to the current situation of Kabul city, a new master plan was prepared in 2012. (2)

Before the planning of the latest master plan, all the areas which were considered to be informal, and sometimes illegal, were included in the new master plan, its legal aspects were found, and the plan was deemed necessary to be upgraded.

Although the growth of informal settlements in the city requires comprehensive studies, the most important reasons for the rapid growth of these areas are as follows.

\section{Immigration to Kabul city}

Lack of prioritization of urban planning, lack of budget for the urban sector and urban management, and inefficiency of the government of Afghanistan have caused the growth of informal areas in Kabul city. Thus, $80 \%$ of the population of Kabul city is now living in informal areas, which account for $69 \%$ of the entire Kabul city. (3) In 
fact, after the intervention of the international community in Afghanistan, there was an influx of immigrants from villages and Afghan immigrants from other countries into Kabul, mainly caused by the political changes. The immigrants, having come in order to avail themselves of the job opportunities and gain better education, did not wait for the government to build them residential houses. They arbitrarily fulfilled their housing needs up to a certain level, in accordance with their abilities and their understanding of the circumstances; otherwise Kabul would now be witnessing a huge percentage of the population being homeless or living in tents.

The research was structured to use questionnaires and personal observations. Various groups of participants were involved in the process of research, such as government employees and local residents. The number of the people who were interviewed is 102 . The people interviewed are from various provinces and different ethnic groups. Of all the individuals interviewed, the majority (62\%) have moved to Kabul because of insecurity, $28 \%$ for a better life and education and $10 \%$ to find a job. (Graph 1)

\section{Complexity of the urban environment}

Complexity of urban environment is another reason for lack of attention to the urban management. In the last 15 years the attention of the Afghan government and the international community has been directed mostly to the security section and rural areas. Furthermore, the international community and the Afghan government have intended to see the development and result of a project as soon as possible, which is why they have selected the rural areas where the implementation of the projects is very easy and simple and no feasibility studies are required as compared to urban areas. Similarly, the National Solidarity Program (NSP) has been implemented successfully as its signs can be seen nearly in each village; in the same way the budget of the Ministry of Rural Rehabilitation and Development is almost 20 times as large as the budget of the Ministry of Urban Development. (4) Despite many efforts by the officials of the Ministry of Urban Development and other related organizations, one can rarely see the positive work of these officials in urban areas because the urban sector has not been a priority for the government.

\section{Unofficial effective presence}

According to the World Bank, the value of the buildings built in informal areas was more than 2.5 billion USD in 2005; now that there are more informal areas than in the previous years, this value also tends to increase. (3) Moreover, compared with those in other developing countries like India, South Africa, Kenya and Slovakia, Afghanistan's informal settlements are of good quality; this indicates that the informal sector of Afghanistan has better conditions to build houses for themselves and this section 
can be even better and can have good investment if there is effective supervision, monitoring and a reduction in corruption. (5)

\section{Ignorance of informal areas}

Like many developing countries, Afghanistan did not pay enough attention to the section of urban development. Based on the master plan of 1978, a certain number of Afghan engineers stressed the illegality of the informal areas and, therefore, opposed any provision of municipal services in these areas. However, this way of thinking has been changed especially by the efforts of international organizations involved in this sector. (6) Lack of interaction of official organizations with the residents of informal areas has caused these areas to extend to the vulnerable areas where floods and earthquakes are more likely.

\section{Conclusion and recommendations}

Several factors have contributed to the growth of informal settlements in Kabul but, in general, insecurity and political changes are the prime factor. The second factor is the desire to get a better life, job and education. The government's view on informal settlements has been varied and considerable.

Urbanization gives the "right to the city" to an individual; thus, the Kabul municipality cannot simply displace informal settlement neighborhoods. Therefore, based on the research and the findings of the study, some of the recommendations are as follows:

- Giving construction permits must apply to all houses, whether in areas of planned and unplanned or informal settlement.

- Upgrading of informal areas should be taken seriously, although such programs were started in 2006 and have been implemented in some areas.

- The development of construction in high-risk areas, such as the range of mountains of Kabul city or areas which are highly exposed to floods, must be prevented.

- Lack of public facilities in informal areas is a serious problem. Public facilities such as schools, clinics, parks, etc.

- The government should consider and implement certain legislation to reduce the access problems in the informal areas.

- The provision of urban infrastructure, especially water supply, waste management, integrated management of surface water and wastewater management in informal areas, requires an effective manner with the participation of the people. 


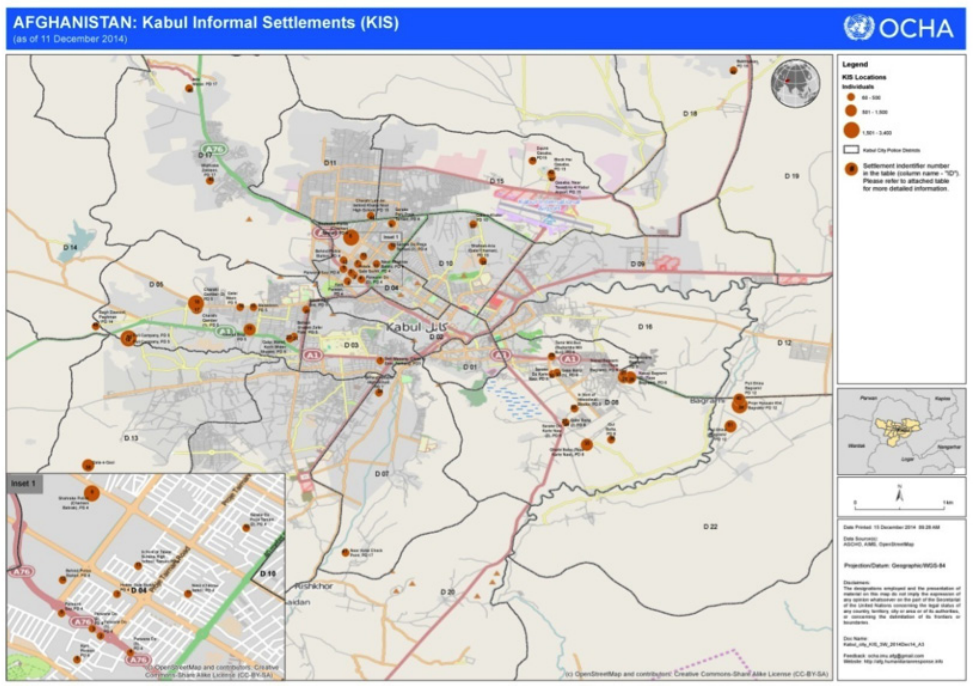

Fig. 1. Kabul Informal settlements 2014 (Source: OCHA 2014)

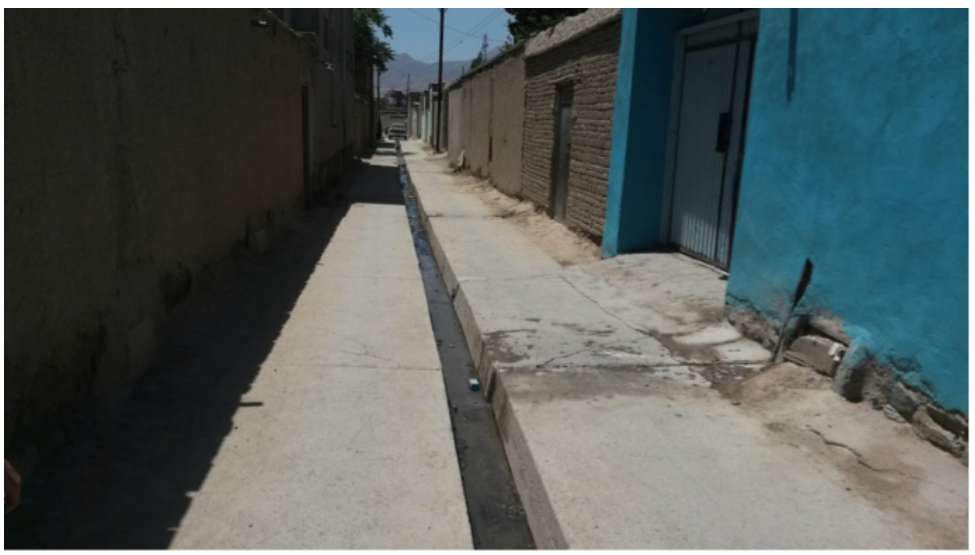

Fig. 2. Informal settlements in Kabul (Source: author, 2016) 


\title{
Reason of displacement from original place
}

\author{
msecurity problem $\quad$ Better life and education \\ mo avail the job $\quad$ interpersonal hostility
}

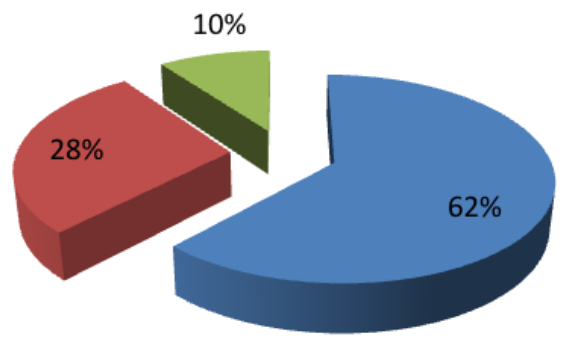

Fig. 3. Reason of displacement from the original place (Source: author, questionnaires, 2016)

\section{Sources}

1. Central Statistics Organization of Afghanistan. Central Statistics [online]. [cit. 2015-Feb]. Dostupné z: http://cso.gov.af/content/files/Population\%20of\%20 Kabul\%20City\%20by\%20District\%20Sex.pdf

2. PROF. LUTfUllaH SAFI, P. A. G. S. The Problem of Homeless in Kabul City. Kabul: National Center for Policy Research, 2012. ISRC 2305-896X.

3. WORLD-BANK. Kabul Urban Policy Notes.. Kabul: World Bank, 2005 [cit. 2014]. Dostupné z: http://databank.worldbank.org/data/views/report/tableview. aspx.

4. National Solidarity Programme [online]. [cit. 2016]. Dostupné z: http://mrrd.gov. af/en/page/69/215

5. UN-HABITAT. Afghanistan Urban Future. Kabul: UN-Habitat, 2014.

6. CAlOgERO PIETRO, A. The Politics of Urbanization in Afghanistan. 2011. Dostupné také z: http://calogero.us/diss/calogero-Pietro_PlanningKabul.pdf 